\title{
Validation List no. 96 Validation of publication of new names and new
combinations previously effectively published
outside the IJSEM
}

Correspondence

Jean Euzéby

j.euzeby@envt.fr
The purpose of this announcement is to effect the valid publication of the following new names and new combinations under the procedure described in the Bacteriological Code (1990 Revision). Authors and other individuals wishing to have new names and/or combinations included in future lists should send three copies of the pertinent reprint or photocopies thereof to the IJSEM

Editorial Office for confirmation that all of the other requirements for valid publication have been met. It is also a requirement of IJSEM and the ICSP that authors of new species, new subspecies and new combinations provide evidence that types are deposited in two recognized culture collections in two different countries (i.e. documents certifying deposition and availability of type strains). It should be noted that the date of valid publication of these new names and combinations is the date of publication of this list, not the date of the original publication of the names and combinations. The authors of the new names and combinations are as given below, and these authors' names will be included in the author index of the present issue and in the volume author index. Inclusion of a name on these lists validates the publication of the name and thereby makes it available in bacteriological nomenclature. The inclusion of a name on this list is not to be construed as taxonomic acceptance of the taxon to which the name is applied. Indeed, some of these names may, in time, be shown to be synonyms, or the organisms may be transferred to another genus, thus necessitating the creation of a new combination.

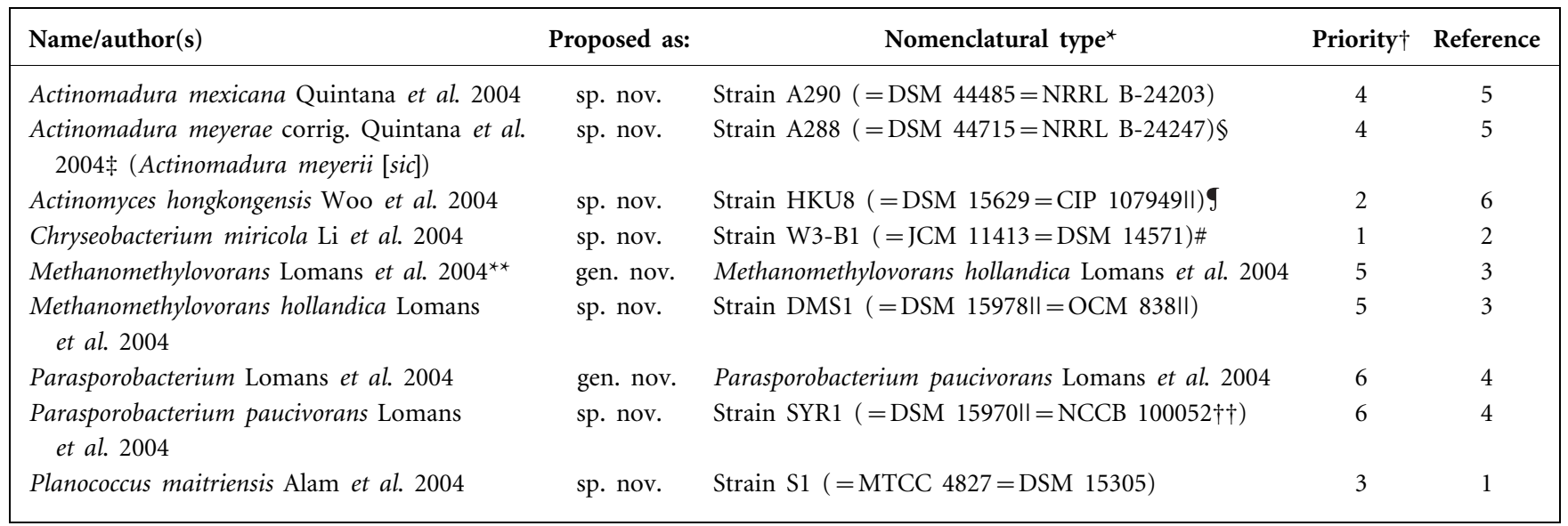

For references to Validation Lists 1-71, see Int J Syst Bacteriol 49 (1999) 1325. Lists 72-95 were published in Int J Syst Evol Microbiol 50 (2000) 3, 423, 949, 1415, 1699, 1953; 51 (2001) 1, 263, 793, 1229, 1619, 1945; 52 (2002) 3, 685, 1075, 1437, 1915; 53 (2003) 1, 373, 627, 935, 1219, 1701; and 54 (2004) 1 .

*Abbreviations: CIP, Collection of the Institut Pasteur, Paris, France; DSM, DSMZ - Deutsche Sammlung von Mikroorganismen und Zellkulturen, Braunschweig, Germany; JCM, Japan Collection of Microorganisms, RIKEN, Saitama, Japan; MTCC, Microbial Type Culture Collection \& Gene Bank, Institute of Microbial Technology, Chandigarh, India; NCCB, Netherlands Culture Collection of Bacteria, NCCB/CBS, Utrecht, The Netherlands; NRRL, Agricultural Research Service Culture Collection, National Center for Agricultural Utilization Research, US Department of Agriculture, Peoria, IL, USA; OCM, Oregon Collection of Methanogens, Oregon Graduate Institute of Science \& Technology, Beaverton, OR, USA.

$\dagger$ Priority number assigned according to the date the documentation and request for validation are received. 
\$Epithet has been corrected on validation according to Rule 61 of the Bacteriological Code.

\$In the effective publication, strain A288 is erroneously cited as DSM $44485=$ NRRL B-24203.

IICulture collection accession numbers provided on request for validation.

The culture collection accession number LMG 21939 is also cited in the effective publication, but the authors did not provide a certificate of deposit from this collection.

\#The culture collection accession number GTC 862 is also cited in the effective publication, but the authors did not provide a certificate of deposit from this collection.

${ }^{*}$ The gender of the generic name is not provided in the effective publication. However, the specific epithet hollandica is an adjective in the feminine gender and Methanomethylovorans must be in the feminine gender.

$\dagger \dagger$ In the effective publication, strain SYR1 is erroneously cited as NCCB 100009.

\section{References}

1. Alam, S. I., Singh, L., Dube, S., Reddy, G. S. N. \& Shivaji, S. (2003). Psychrophilic Planococcus maitriensis sp. nov. from Antarctica. Syst Appl Microbiol 26, 505-510.

2. Li, Y., Kawamura, Y., Fujiwara, N., Naka, T., Liu, H., Huang, X., Kobayashi, K. \& Ezaki, T. (2003). Chryseobacterium miricola sp. nov., a novel species isolated from condensation water of space station Mir. Syst Appl Microbiol 26, 523-528.

3. Lomans, B. P., Maas, R., Luderer, R., Op den Camp, H. J. M., Pol, A., van der Drift, C. \& Vogels, G. D. (1999). Isolation and characterization of Methanomethylovorans hollandica gen. nov., sp. nov., isolated from freshwater sediment, a methylotrophic methanogen able to grow on dimethyl sulfide and methanethiol. Appl Environ Microbiol 65, 3641-3650.
4. Lomans, B. P., Leijdekkers, P., Wesselink, J. J., Bakkes, P., Pol, A., van der Drift, C. \& Op den Camp, H. J. M. (2001). Obligate sulfide-dependent degradation of methoxylated aromatic compounds and formation of methanethiol and dimethyl sulfide by a freshwater sediment isolate, Parasporobacterium paucivorans gen. nov., sp. nov. Appl Environ Microbiol 67, 4017-4023.

5. Quintana, E. T., Trujillo, M. E. \& Goodfellow, M. (2003). Actinomadura mexicana sp. nov. and Actinomadura meyerii sp. nov., two novel soil sporoactinomycetes. Syst Appl Microbiol 26, 511-517.

6. Woo, P. C. Y., Fung, A. M. Y., Lau, S. K. P., Teng, J. L. L., Wong, B. H. L., Wong, M. K. M., Hon, E., Tang, G. W. K. \& Yuen, K. Y. (2003). Actinomyces hongkongensis sp. nov. A novel Actinomyces species isolated from a patient with pelvic actinomycosis. Syst Appl Microbiol 26, 518-522. 